\title{
Factors associated with functional impairment of elderly patients in the emergency departments
}

\author{
Fatores associados ao comprometimento funcional de idosos \\ internados no serviço de emergência
}

\begin{abstract}
Maria Carolina Barbosa Teixeira Lopes ${ }^{1}$, Julieth Santana Silva Lage ${ }^{1}$, Cássia Regina Vancini-Campanharo ${ }^{1}$, Meiry Fernanda Pinto Okuno ${ }^{1}$, Ruth Ester Assayag Batista ${ }^{1}$
\end{abstract}

\begin{abstract}
Objective: To assess the functional capacity of elderly patients in the emergency department as to Basic and Instrumental Activities of Daily Living. Methods: A cross-sectional study of 200 elderly patients admitted to the emergency department of a teaching hospital in São Paulo (SP), Brazil. The functional capacity of the elderly was assessed by the Katz index and Lawton \& Brody scale. Statistical analyses were performed using analysis of variance, Bonferroni correction, $\chi^{2}$ test, or the likelihood ratio test. Results: Most seniors were independent $(65 \%)$, and the degree of dependence was related to age, female gender, being single and widowed, and presence of cerebrovascular disease and dementia. The more dependent elderly for Instrumental Activities of Daily Living had increased dependence for Basic Activities. Conclusion: We emphasize the importance of assessing the functional capacity of the elderly in the emergency department as it provides data for the nursing care in order to minimize or to avoid their functional impairment.
\end{abstract}

Keywords: Aged; Activities of daily living; Emergency medical services; Inpatients

\section{RESUMO}

Objetivo: Avaliar a capacidade funcional dos idosos internados em um serviço de emergência para as Atividades Básicas e Instrumentais de Vida Diária. Métodos: Estudo transversal com 200 idosos internados no serviço de emergência de um hospital universitário do município de São Paulo (SP). A capacidade funcional dos idosos foi avaliada pelas escala de Katz e a de Lawton e Brody. Os testes estatísticos utilizados foram análise de variância, correção de Bonferroni, $\chi^{2}$ ou da razão de verossimilhança. Resultados: A maioria dos idosos era independente (65\%), e o grau de dependência relacionou-se a idade, sexo feminino, ser solteiro e viúvo, e apresentar doenças cerebrovasculares e demências. Os idosos mais dependentes para Atividades Instrumentais de Vida Diária apresentaram maior dependência para as Atividades Básicas. Conclusão: Ressalta-se a importância da avaliação da capacidade funcional do idoso no serviço de emergência, já que esta fornece dados para a assistência de enfermagem de modo a minimizar ou evitar seu comprometimento funcional.

Descritores: Idoso; Atividades cotidianas; Serviços médicos de emergência; Pacientes internados

\section{INTRODUCTION}

Aging in the population is characterized as a worldwide process associated with the reduction of fertility rate and increased longevity. ${ }^{(1,2)}$ The prevalence of noncommunicable chronic diseases accompanied the increase in life expectancy. Most elderly have chronic diseases and many individuals present with more than one condition, ${ }^{(3)}$ which can compromise the functional capacity of the aged person and accelerate the fragility syndrome process. ${ }^{(4)}$

For the most part, the elderly population has an independent and autonomous life, but a part of it becomes vulnerable to adverse events, since increased life expectancy is accompanied by physiological alterations and comorbidities that can compromise functional capacity. ${ }^{(5)}$ Functional incapacity is measured by the report of difficulties or the need for help to carry out daily living activities. The basic Activities of Daily Living (ADL) are activities essential for self-care, which may be evaluated by Katz Index, ${ }^{(6)}$ and the Instrumental

\footnotetext{
${ }^{1}$ Universidade Federal de São Paulo, São Paulo, SP, Brazil.

Corresponding author: Meiry Fernanda Pinto Okuno - Rua Napoleão de Barros, 754 - Vila Clementino - Zip code: 04024-002 - São Paulo, SP, Brazil - Phone: (55 11) 5576-4430 - E-mail: mf.pinto@unifesp.br Received on: Jan 30, 2015 - Accepted on: Apr 23, 2015

Conflict of interest: none.

DOI: 10.1590/\$1679-45082015A03327
} 
Activities of Daily Living (IADL) are more complex activities, which require an adaptation to the environment and are evaluated by the Lawton \& Brody scale. ${ }^{(7)}$

Within this context, chronic diseases and their external causes configure a growing concern as to functionality of the elderly, since they commonly are associated with increased morbidity, hospitalization, readmission to emergency departments, ${ }^{(8)}$ institutionalization ${ }^{(9)}$ and mortality. ${ }^{(10,11)}$ In this way, during hospitalization of the elderly in the emergency department, assessing their functional capacity is necessary, since it provides important data for nursing care and that of other professionals, who can intervene or avoid loss of functional capacity and prevent complications. Additionally, individualized care during hospitalization and patient orientation at discharge may contribute towards a reduction in readmission to emergency departments, as it is associated with a better quality of care.

\section{OBJECTIVE}

To evaluate the functional capacity of the elderly admitted to the emergency department as to Basic and Instrumental Activities of Daily Living.

\section{METHODS}

An epidemiological cross-sectional study carried out at the emergency department of the Hospital São Paulo, between April and July 2013. Patients aged 60 years or more, i.e., considered aged, were included, as per the United Nations (UN) classification for developing countries. ${ }^{(12)}$ The sample was composed of 200 elderly individuals admitted to the emergency department, of both sexes, non-institutionalized, who agreed to participate in the study and signed the Informed Consent Form. The research project was approved by the Research Ethics Committee of the Universidade Federal de São Paulo, under protocol number 220.550, CAAE: 12704613.0.0000.5505.

The sociodemographic and clinical variables studied were age, sex, marital status, level of schooling, occupation, family income, and presence of a caregiver, comorbidities, and medications in use. The functional capacity of the elderly to perform ADL and IADL was assessed using the Katz index ${ }^{(6)}$ and the Lawton \& Brody scale, ${ }^{(7)}$ respectively.

The Katz index measures performance and dependence of the individual in six items of activities of self-care, which are feeding, sphincter control/ continence, transferring, personal hygiene/toileting, dressing, and bathing. Scoring varies from 1 to 6 , in which $\leq 2$ corresponds to the maximal degree of dependence; from 3 to 5 they are classified as having partial dependence, and a score of 6 , as independent. ${ }^{(6)}$

The Lawton \& Brody scale, used to identify the degree of dependence for IADL, which are related to participation of the individual within the social context, is constituted by nine questions with three options each: the first indicates independence; the second, partial dependence; and the third, total dependence. Once the degrees of independence and dependence are defined, one proceeds to the analysis on three levels ("without help", "with partial help", and "cannot perform"), and for score calculation, 3, 2, and 1 points, respectively, with a maximal score of 27 . The greater the score, the greater the degree of independence. ${ }^{(7)}$

Completing the form was done with the elderly or, in the case of cognitive compromise diagnosed by the physician, with the caregiver, at one time, with an average duration of 40 minutes.

To compare the age with the total score of the Katz index and the Lawton \& Brody scale, variance analysis (ANOVA) was used, and for multiple comparisons, Bonferroni correction. Comparison of the categorical variables with the total score of the Katz index and Lawton \& Brody scale was performed by the $\chi^{2}$ test or the likelihood ratio test. The significance level was considered $5 \%$.

\section{RESULTS}

Mean age of the elderly was 75.3 years, most were men $(108 ; 54 \%)$, retired $(177 ; 88.5 \%)$, with a low level of schooling $(147 ; 73.5 \%)$, and low income $(103 ; 51.5 \%)$.

Most of the elderly in this study were independent $(130 ; 65 \%)$ for the ADL and partially dependent (154; $77 \%$ ) for the IADL.

The elderly with partial and total dependence were older than those who were independent. Elderly women presented with greater dependence when compared to men. The single and widowed men were more dependent than the married and divorced/ separated men. The elderly men with jobs showed a greater percentage of independence relative to the rest. Patients with cerebrovascular diseases and dementia were more dependent than those who did not suffer from these conditions. Of the elderly classified with total dependence and independence, most did not use psychotropic medications when compared to those classified as partially independent (Table 1).

Table 2 shows that the greater the dependence of the elderly for IADL, the greater their dependence for ADL. 
Table 1. Variables that showed an association with the Lawton \& Brody scale $(\mathrm{n}=200)$. São Paulo (SP), Brazil, 2013

\begin{tabular}{|c|c|c|c|c|}
\hline Variables & $\begin{array}{c}\text { Totally } \\
\text { dependent } \\
\text { n (\%) }\end{array}$ & $\begin{array}{c}\text { Partially } \\
\text { dependent } \\
\text { n (\%) }\end{array}$ & $\begin{array}{l}\text { Independent } \\
\text { n (\%) }\end{array}$ & $\begin{array}{c}\mathbf{p} \\
\text { value }\end{array}$ \\
\hline Age, mean (SD) & $78.71(9.91)$ & $76.03(8.88)$ & $69.55(6.45)$ & 0.0004 \\
\hline \multicolumn{5}{|l|}{ Sex } \\
\hline Male & $3(2.8)$ & $90(83.3)$ & $15(13.9)$ & \multirow[t]{2}{*}{0.0057} \\
\hline Female & $14(15.2)$ & $64(69.6)$ & $14(15.2)$ & \\
\hline \multicolumn{5}{|l|}{ Presence of caregiver } \\
\hline Yes & $16(9.8)$ & $129(78.7)$ & $19(11.6)$ & \multirow[t]{2}{*}{0.0253} \\
\hline No & $1(2.8)$ & $25(69.4)$ & $10(27.8)$ & \\
\hline \multicolumn{5}{|l|}{ Marital status } \\
\hline Married & $3(3.1)$ & $81(82.7)$ & $14(14.3)$ & \multirow[t]{4}{*}{0.0413} \\
\hline Single & $3(14.3)$ & $16(76.2)$ & $2(9.5)$ & \\
\hline Widowed & $11(16.9)$ & $44(67.7)$ & $10(15.4)$ & \\
\hline Divorced/separated & - & $13(81.3)$ & $3(18.8)$ & \\
\hline \multicolumn{5}{|l|}{ Occupation } \\
\hline Employed & - & $6(42.9)$ & $8(57.1)$ & \multirow[t]{4}{*}{0.0020} \\
\hline Unemployed & - & $3(100)$ & - & \\
\hline Retired/pensioner & $17(9.6)$ & $140(79.1)$ & $20(11.3)$ & \\
\hline Housewife & - & $5(83.3)$ & $1(16.7)$ & \\
\hline \multicolumn{5}{|c|}{ Cerebrovascular diseases } \\
\hline No & $9(5.7)$ & $123(78.3)$ & $25(15.9)$ & \multirow[t]{2}{*}{0.0098} \\
\hline Yes & $8(20)$ & $29(72.5)$ & $3(7.5)$ & \\
\hline \multicolumn{5}{|l|}{ Dementia } \\
\hline No & $12(6.5)$ & $146(78.5)$ & $28(15.1)$ & \multirow[t]{2}{*}{0.0007} \\
\hline Yes & $5(45.5)$ & $6(54.5)$ & - & \\
\hline \multicolumn{5}{|c|}{ Medication/psychotropic } \\
\hline No & $11(7.1)$ & $126(81.3)$ & $18(11.6)$ & \multirow[t]{2}{*}{0.0076} \\
\hline Yes & $4(17.4)$ & $12(52.2)$ & $7(30.4)$ & \\
\hline
\end{tabular}

\section{DISCUSSION}

This study showed a greater percentage of male elderly individuals, retired, with low level of schooling and income, like other investigations that evaluated the profile of aged patients admitted to the emergency department, ${ }^{(5)}$ seen at an emergency department, ${ }^{(13)}$ and another study that included institutionalized elderly individuals. ${ }^{(14)}$ However, other national and international studies pointed towards the prevalence of women..$^{(10,15-17)}$ The mean age of the elderly was 75.3 years, which was considered high and similar to that of other studies, ${ }^{(15,18)}$ with elderly people admitted to the emergency department (73.8 years). ${ }^{(5)}$

As to the degree of dependence for ADL, 65\% of the aged of this study were independent, $11 \%$ were partially dependent, and $324 \%$ dependent. The percentage of independent elderly was similar to that recorded in literature, ${ }^{(11,15)}$ such as, for example, an American study with percentage of independence of $56.1 \%$ for women and $77.7 \%$ for men. ${ }^{(11)}$ The results of the study carried out among the aged, which assessed the association between functional capacity and the use of healthcare services, who resided in the metropolitan region of Belo Horizonte, showed that $64.2 \%$ of the elderly were independent for performing ADL.(19) As to the categories of dependence for ADL, the results obtained in this study differed from those from the literature, which describes less dependent elderly (6.7\%) than partially dependent elderly $(30 \%)$. $^{(15)}$

For the IADL, the frequency in the category of independent elderly was lower $(14.5 \%)$ when compared

Table 2. Association between domains of the Lawton \& Brody scale and Katz index

\begin{tabular}{|c|c|c|c|c|c|}
\hline \multirow[b]{2}{*}{ Lawton scale } & \multicolumn{5}{|c|}{ Katz Index } \\
\hline & $\begin{array}{c}\text { Very dependent } \\
\text { n (\%) } \\
\end{array}$ & $\begin{array}{c}\text { Dependent } \\
\text { n (\%) } \\
\end{array}$ & $\begin{array}{c}\text { Independent } \\
\mathbf{n}(\%) \\
\end{array}$ & $\begin{array}{l}\text { Total } \\
\text { n (\%) }\end{array}$ & p value \\
\hline Dependence & $44(71)$ & $11(17.7)$ & $7(11.3)$ & $62(100)$ & $<0.0001$ \\
\hline Partial dependence & $4(12.9)$ & $9(29)$ & $18(58.1)$ & $31(100)$ & \\
\hline Independence & - & $2(1.9)$ & $105(98.1)$ & $107(100)$ & \\
\hline \multicolumn{6}{|l|}{ Housekeeping tasks } \\
\hline Dependence & $47(57.3)$ & $14(17.1)$ & $21(25.6)$ & $82(100)$ & $<0.0001$ \\
\hline Partial dependence & - & $8(11.9)$ & $59(88.1)$ & $67(100)$ & \\
\hline Independence & $1(2)$ & - & $50(98)$ & $51(100)$ & \\
\hline Total & $48(24)$ & $22(11)$ & $130(65)$ & $200(100)$ & \\
\hline Independence & $1(2)$ & - & $49(98)$ & $50(100)$ & \\
\hline Total & $48(24)$ & $22(11)$ & $130(65)$ & $200(100)$ & \\
\hline
\end{tabular}


...Continuation

Table 2. Association between domains of the Lawton \& Brody scale and Katz index

\begin{tabular}{|c|c|c|c|c|c|}
\hline \multirow[b]{2}{*}{ Lawton scale } & \multicolumn{5}{|c|}{ Katz Index } \\
\hline & $\begin{array}{c}\text { Very dependent } \\
\mathbf{n}(\%)\end{array}$ & $\begin{array}{c}\text { Dependent } \\
\text { n (\%) }\end{array}$ & $\begin{array}{c}\text { Independent } \\
\mathbf{n}(\%)\end{array}$ & $\begin{array}{l}\text { Total } \\
\text { n (\%) }\end{array}$ & p value \\
\hline \multicolumn{6}{|l|}{ Managing medication } \\
\hline Dependence & $24(92.3)$ & $1(3.8)$ & $1(3.8)$ & $26(100)$ & $<0.0001$ \\
\hline Partial dependence & $22(26.8)$ & $14(17.1)$ & $46(56.1)$ & $82(100)$ & \\
\hline Independence & $2(2.2)$ & $7(7.6)$ & $83(90.2)$ & $92(100)$ & \\
\hline Total & $48(24)$ & $22(11)$ & $130(65)$ & $200(100)$ & \\
\hline \multicolumn{6}{|c|}{ Capacity to use the telephone } \\
\hline Dependence & $21(75)$ & $3(10.7)$ & $4(14.3)$ & $28(100)$ & $<0.0001$ \\
\hline Partial dependence & $14(56)$ & $2(8)$ & $9(36)$ & $25(100)$ & \\
\hline Independence & $13(8.8)$ & $17(11.6)$ & $117(79.6)$ & $147(100)$ & \\
\hline Total & $48(24)$ & $22(11)$ & $130(65)$ & $200(100)$ & \\
\hline \multicolumn{6}{|l|}{ Managing money } \\
\hline Dependence & $45(73.8)$ & $9(14.8)$ & $7(11.5)$ & $61(100)$ & $<0.0001$ \\
\hline Partial dependence & $2(4.7)$ & $8(18.6)$ & $33(76.7)$ & $43(100)$ & \\
\hline Independence & $1(1)$ & $5(5.2)$ & 90 (93.8) & $96(100)$ & \\
\hline Total & $48(24)$ & $22(11)$ & $130(65)$ & $200(100)$ & \\
\hline \multicolumn{6}{|l|}{ Purchases } \\
\hline Dependence & $45(73.8)$ & $9(14.8)$ & $7(11.5)$ & $61(100)$ & $<0.0001$ \\
\hline Partial dependence & $3(6.3)$ & $11(22.9)$ & $34(70.8)$ & $48(100)$ & \\
\hline Independence & $0(0)$ & $2(2.2)$ & $89(97.8)$ & $91(100)$ & \\
\hline Total & $48(24)$ & $22(11)$ & $130(65)$ & $200(100)$ & \\
\hline \multicolumn{6}{|l|}{ Use of transportation } \\
\hline Dependence & $28(90.3)$ & $1(3.2)$ & $2(6.5)$ & $31(100)$ & $<0.0001$ \\
\hline Partial dependence & $19(21.6)$ & $19(21.6)$ & $50(56.8)$ & $88(100)$ & \\
\hline Independence & $1(1.2)$ & $2(2.5)$ & $78(96.3)$ & $81(100)$ & \\
\hline Total & $48(24)$ & $22(11)$ & $130(65)$ & $200(100)$ & \\
\hline
\end{tabular}

to the others, and a high percentage of partially dependent patients was noted $(77 \%)$.

In this study, a greater degree of dependence was seen associated with greater age, female sex, being single or widowed, retired and a pensioner, and having cerebrovascular diseases. In agreement with these results, some investigations, ${ }^{(10,15,18,20)}$ including one multicenter study with 760 patients, ${ }^{(18)}$ found an association between greater dependence with more advanced age and female sex. An American study evaluated the impact of functional capacity on life expectancy of the elderly and showed that the modification to worse functional conditions increased by $10 \%$ per year with age, and by $5 \%$ in mortality rates. It was further noted that the impact of the deficiencies was greater in women. ${ }^{(10)}$

The reduction of work activities due to retirement and the frequent occurrence of chronic conditions that lead to decreased physical capacities in this phase of life is a possible reason for the prevalence of dependence found among the retired persons and pensioners of this study. A study carried out in the city of Cuiabá with the elderly also verified that the greatest degree of dependence was associated with the elderly without work-related activities. ${ }^{(21)}$

Some diseases are associated with worse functional conditions, including cardiovascular and cerebrovascular disorders and dementia. ${ }^{(11,22)}$ An analysis of 329 elderly individuals from the state of Minas Gerais showed an association with some diseases, such as diabetes mellitus, stroke and heart diseases, with dependence for ADL and IADL. ${ }^{(18,22)}$ In this study, dependence was greater in the elderly with cerebrovascular diseases and dementia. These health conditions result in a higher number of medical visits and longer length of hospital stay. ${ }^{(11)}$ Moreover, after hospital discharge, the patient may present with a decline in functional capacity over time. ${ }^{(23,24)}$ Data from the emergency department of an Australian hospital, where the dependence of patients was evaluated one and three months after discharge from the emergency department, showed that between the discharge and a one-month interval, $26.4 \%$ presented 
a drop in all IADL scores, and up to the third month, this percentage rose to $36.7 \%$. $^{(24)}$

Association between the Lawton \& Brody scale with Katz index showed a significant correlation $(\mathrm{p}<0.0001)$ for all the domains of the Lawton \& Brody scale, i.e., the greater the dependence in the domains of this scale, the greater the dependence according to Katz index. The domains that presented with the highest percentage of dependence in IADL were managing medication $(92.3 \%)$ and use of means of transportation (90.3\%); they also showed an association with the high dependence for the ADL. A divergent result was noted in another study, in which the activities of housekeeping were the most compromised. ${ }^{(11)}$ Commonly, the decline in functional capacity of the aged individual begins in the IADL, possibly because they are related to activities that require from the individual better physical and cognitive conditions.

The limitation of this study lies in the fact that it was conducted in one single teaching hospital, which delivered care for the public healthcare system and may not represent other populations.

Dependence is not considered a permanent state but a dynamic process of which evolution can be modified, prevented, or reduced. ${ }^{(25,26)}$ For this process to occur, qualified professionals who are committed to helping the elderly are necessary, and they need to recognize potential factors that favor functional impairment, so that prevention and intervention measures might be established to improve autonomy and independence, leading to better quality of life. It is important to point out the role of the caregiver in cases of dependence, since they should be oriented by healthcare professionals.

\section{CONCLUSION}

The elderly admitted to the emergency department presented with higher ages, and most were men, retired, with low levels of schooling and income. Application of the functional capacity evaluation scales showed that most of the elderly were independent for the basic Activities of Daily Living and partially dependent for the Instrumental Activities of Daily Living. The older female individuals, both single and widowed, and with cerebrovascular diseases and dementia, were related to greater functional dependence.

There was a significant association between the Lawton \& Brody scale and Katz index, that is, the greater the dependence of the elderly considering the domains of the Lawton \& Brody Scale, the greater was their dependence on the Katz Index. The domains with greatest percentages of dependence in the Instrumental
Activities of Daily Living were managing medication $(92.3 \%)$ and the use of means of transportation, in addition to association with the high dependence for the basic Activities of Daily Living.

\section{REFERENCES}

1. Instituto Brasileiro de Geografia e Estatística (IBGE). Atlas do Censo Demográfico 2010. Rio de Janeiro: IBGE; 2013

2. Carneiro LA, Campino AC, Leite F, Rodrigues CG, Santos GM, Silva AR. Envelhecimento populacional e os desafios para o sistema de saúde brasileiro [Internet]. São Paulo: Instituto de Estudos de Saúde Suplementar; 2013. [citado 2015 Mai 1]. Disponível em: www.iess.org.br/envelhecimentopop2013.pdf

3. Tenório DM, Camacho AC. Identificação dos agravos de saúde que levam os idosos ao serviço de emergência. Rev Enferm UFPE On Line. 2015;9 (supl.1): 457-65.

4. Nogueira SL, Ribeiro RC, Rosado LE, Franceschini SC, Ribeiro AQ, Pereira ET. Fatores determinantes da capacidade funcional em idosos longevos. Rev Bras Fisioter. 2010;14(4):322-9.

5. Storti LB, Fabrício-Whebe SC, Kusumota L, Rodrigues RA, Marques S. Fragilidade de idosos internados na clínica médica da unidade de emergência de um hospital geral terciário. Texto \& Contexto Enferm. 2013;22(2):452-9.

6. Lino VT, Pereira SE, Camacho LA, Ribeiro Filho ST, Buksman S. Adaptação transcultural da Escala de Independência em Atividades da Vida Diária (Escala de Katz). Cad Saúde Pública. 2008;24(1):103-12. English.

7. Lawton MP, Brody EM. Assessment of older people: self-maintaining and instrumental activities of daily living. Gerontologist. 1969;9(3):179-86.

8. Acosta AM, Lima MA. Características de usuários frequentes de serviços de urgência: revisão integrativa. Rev Eletr Enf. 2013;15(2):564-73.

9. Melo SC, Leal SM, Vargas MA. Internação de idosos por causas externas em um hospital público de trauma. Enfermagem em Foco. 2011;2(4):226-30.

10. Keeler E, Guralnik JM, Tian H, Wallace RB, Reuben DB. The impact of functional status on life expectancy in older persons. J Gerontol A Biol Sci Med Sci. 2010;65(7):727-33.

11. Millán-Calenti JC, Tubío J, Pita-Fernández S, González-Abraldes I, Lorenzo T, Fernández-Arruty $T$, et al. Prevalence of functional disability in activities of daily living (ADL), instrumental activities of daily living (IADL) and associated factors, as predictors of morbidity and mortality. Archives of Gerontol and Geriatr. 2010;50(3):306-10

12. Organização das Nações Unidas - ONU. Assembleia mundial sobre envelhecimento: Resolução 39/125. Viena: ONU; 1982.

13. Rodrigues CC, Ribeiro RC. Perfil epidemiológico dos idosos atendidos na emergência de um hospital escola. Arq Ciênc Saúde. 2012;9(2):37-41.

14. Oliveira PH, Mattos IE. Prevalência e fatores associados à incapacidade funcional em idosos institucionalizados no Município de Cuiabá, Estado de Mato Grosso, Brasil, 2009-2010. Epidemiol Serv Saúde. 2012;21(3):395-406.

15. Paula AF, Ribeiro LH, D’Elboux MJ, Guariento ME. Avaliação da capacidade funcional, cognição e sintomatologia depressiva em idosos atendidos em ambulatório de Geriatria. Rev Bras Clin Med. 2013;11(3):212-8.

16. Fhon JR, Wehbe SC, Vendruscolo TR, Stackfleth R, Marques S, Rodrigues RA Accidental falls in the elderly and their relation with functional capacity. Rev Lat Am Enfermagem. 2012;20(5):927-934.

17. Serbim AK, Gonçalves AV, Paskulin LM. [Sociodemographics, health, and social support to senior users of emergency services]. Rev Gaucha Enferm. 2013;34(1):55-63. Portuguese.

18. Mattos IE, do Carmo CN, Santiago LM, Mattos LL. Factors associated with functional incapacity in elders living in long stay institutions in Brazil: a crosssectional study. BMC Geriatric. 2014;14:47.

19. Fialho CB, Lima-Costa MF, Giacomin KC, Loyola Filho AL. [Disability and use of health services by the elderly in Greater Metropolitan Belo Horizonte, Minas Gerais State, Brazil: a population-based study]. Cad Saúde Pública. 2014;30(3):599-610. Portuguese. 
20. Aires M, Paskulin LM, de Morais EP. Functional capacity of elder elderly: comparative study in three regions of Rio Grande do Sul. Rev Lat Am Enfermagem. 2010;18(1):11-7.

21. Sudré MR, Reiners AA, Nakagawa JT, Azevedo RC, Floriano LA, Morita LH. Prevalência de dependência em idosos e fatores de risco associados. Acta Paul Enferm. 2012;25(6):947-53.

22. Barbosa BR, Almeida JM, Barbosa MR, Rossi-Barbosa LA. Avaliação da capacidade funcional dos idosos e fatores associados à incapacidade. Cien Saúde Colet. 2014;19(8):3317-25.

23. Abelha FJ, Botelho M, Fernandes V, Barros H. Avaliação da qualidade de vida e mortalidade em pacientes com eventos cardíacos graves no pós-operatório. Rev Bras Anestesiol. 2010;60(3):268-84.

24. Grimmer K, Beaton K, Hendry K. Identifying functional decline: a methodological challenge. Patient Rel Outcome Measures. 2013;4:37-48.

25. Mendes GD, Miranda SM, Borges MM. Saúde do cuidador de idosos: um desafio para o cuidado. Rev Enferm Integr. 2010;3(1):408-21.

26. Sthal HC, Berti HW, Palhares VC. Grau de dependência de idosos hospitalizados para realização das atividades básicas da vida diária. Texto \& Contexto Enferm. 2011;20(1):59-67. 